AperTO - Archivio Istituzionale Open Access dell'Università di Torino

A novel 3q29 deletion associated with autism, intellectual disability, psychiatric disorders, and obesity

This is a pre print version of the following article:

Original Citation:

Availability:

This version is available http://hdl.handle.net/2318/1563573

since 2016-08-19T10:53:34Z

Published version:

DOI:10.1002/ajmg.b.32406

Terms of use:

Open Access

Anyone can freely access the full text of works made available as "Open Access". Works made available under a Creative Commons license can be used according to the terms and conditions of said license. Use of all other works requires consent of the right holder (author or publisher) if not exempted from copyright protection by the applicable law. 
This is the author's final version of the contribution published as:

Biamino, Elisa; Di Gregorio, Eleonora; Belligni, Elga Fabia; Keller, Roberto; Riberi, Evelise; Gandione, Marina; Calcia, Alessandro; Mancini, Cecilia; Giorgio, Elisa; Cavalieri, Simona; Pappi, Patrizia; Talarico, Flavia; Fea, Antonio M; De Rubeis, Silvia; Cirillo Silengo, Margherita; Ferrero, Giovanni Battista; Brusco, Alfredo. A novel 3q29 deletion associated with autism, intellectual disability, psychiatric disorders, and obesity. AMERICAN JOURNAL OF MEDICAL GENETICS. PART B, NEUROPSYCHIATRIC GENETICS. 171 (2) pp: 290-299.

DOI: 10.1002/ajmg.b.32406

The publisher's version is available at:

http://doi.wiley.com/10.1002/ajmg.b.32406

When citing, please refer to the published version.

Link to this full text:

http://hdl.handle.net/2318/1563573 


\section{A novel 3q29 deletion associated with autism, intellectual disability, psychiatric disorders and obesity.}

Elisa Biamino ${ }^{1}$, Eleonora Di Gregorio ${ }^{2}$, Elga Fabia Belligni ${ }^{1}$, Roberto Keller ${ }^{3}$, Evelise Riberi ${ }^{1}$, Marina Gandione ${ }^{4}$, Alessandro Calcia ${ }^{5}$, Cecilia Mancini ${ }^{5}$, Elisa Giorgio ${ }^{5}$, Simona Cavalieri ${ }^{2,5}$, Patrizia Pappi ${ }^{2}$, Flavia Talarico ${ }^{2}$, Antonio M. Fea ${ }^{6}$, Silvia De Rubeis ${ }^{7,8}$, Margherita Cirillo Silengo ${ }^{1}$, Giovanni Battista Ferrero ${ }^{1 *}$, Alfredo Brusco ${ }^{2,5^{*}}$

${ }^{1}$ University of Torino, Department of Public Health and Pediatrics, Torino, 10126, Italy

${ }^{2}$ Città della Salute e della Scienza University Hospital, Medical Genetics Unit, Torino, 10126, Italy

${ }^{3}$ Adult Autism Center, ASL TO2, Torino, 10149, Italy

${ }^{4}$ University of Torino, Department of Neuropsychiatry, Torino, 10126, Italy

${ }^{5}$ University of Torino, Department of Medical Sciences, Torino, 10126, Italy

${ }^{6}$ University of Torino, Department of Surgical Sciences, Torino, 10126, Italy

${ }^{7}$ Seaver Autism Center for Research and Treatment; Icahn School of Medicine at Mount Sinai, New York, 10029 NY, USA

${ }^{8}$ Department of Psychiatry, Icahn School of Medicine at Mount Sinai, New York, 10029 NY

* These authors equally contributed to the work

Corresponding authors: Alfredo Brusco PhD, University of Torino, Department of Medical Sciences, via Santena 19, 10126, Torino, Italy. Fax +390116706582; e-mail: alfredo.brusco@unito.it

Giovanni Battista Ferrero MD, Department of Public Health and Pediatrics, Torino, 10126, Italy, email: giovannibattista.ferrero@unito.it

Keywords: contiguous gene syndrome, intellectual disability, schizophrenia, autistic spectrum disorder, obesity.

Running title: $3 q 29$ proximal deletion 


\section{ABSTRACT}

Copy number variation (CNV) has been associated with a variety of neuropsychiatric disorders, including intellectual disability/developmental delay (ID/DD), autism spectrum disorder (ASD), and schizophrenia (SCZ). Often, individuals carrying the same pathogenic CNV display high clinical variability. By array-CGH analysis, we identified a novel familial 3q29 deletion (1.36 Mb), centromeric to the $3 \mathrm{q} 29$ deletion region, which manifests with variable expressivity. The deletion was identified in a three years old girl diagnosed with ID/DD and autism and segregated in six family members, all affected by severe psychiatric disorders including schizophrenia, major depression, anxiety disorder and personality disorder. All individuals carrying the deletion were overweight or obese, and anomalies compatible with optic atrophy were observed in three out of four cases examined.

Amongst the ten genes encompassed by the deletion, the haploinsufficiency of Optic Atrophy 1 (OPA1), associated with autosomal dominant optic atrophy, is likely responsible for the ophthalmological anomalies. We hypothesize that the haploinsufficiency of ATPase type 13A4 (ATP13A4) and/or Hairy/Enhancer of Split Drosophila homolog 1 (HES1) contribute to the neuropsychiatric phenotype, while HES1 deletion might underlie the overweight/obesity.

In conclusion, we propose a novel contiguous gene syndrome due to a proximal $3 \mathrm{q} 29$ deletion variably associated with autism, ID/DD, psychiatric traits and overweight/obesity. 


\section{INTRODUCTION}

Copy number variation $(\mathrm{CNV})$ is a common form of genetic variation in the human genome (Zarrei et al. 2015) and presents as a continuous spectrum from population polymorphisms to severe Mendelian conditions (Sebat et al. 2004; Zarrei et al. 2015). Variable expressivity is a common finding amongst patients sharing a pathogenic $\mathrm{CNV}$, and deletions or duplications of a given region may be associated with distinct or mirror phenotypes (Jacquemont et al. 2011; Weischenfeldt et al. 2013). Recently, an increased burden of large $(>500 \mathrm{~kb})$, rare $(<1 \%)$ CNVs has been identified in an array of neuropsychiatric disorders (Sullivan et al. 2012). The most frequently detected are 22q11 deletions, and deletions/duplications at 1q21, 15q11, and 15q13 (International Schizophrenia 2008; Kirov et al. 2009a; Stefansson et al. 2008). More recently, 17q12 deletions (Moreno-De-Luca et al. 2010), 3q29 deletions/duplications (Levinson et al. 2011; Mulle et al. 2010) and 16p11 deletions/duplications (McCarthy et al. 2009) have been identified.

Several neuropsychiatric phenotypes are associated with CNV, including bipolar disorder, (Green et al. 2015; Malhotra et al. 2011), schizophrenia (SCZ) (International Schizophrenia 2008; Kirov et al. 2012; Malhotra et al. 2011; Stefansson et al. 2008) and autism spectrum disorder (ASD) (Levy et al. 2011; Marshall et al. 2008; Pinto et al. 2014; Pinto et al. 2010; Sanders et al. 2011; Sebat et al. 2007). In particular, de novo CNVs have a high burden on the genetic risk for these disorders (Malhotra et al. 2011; Pinto et al. 2010; Sanders et al. 2011; Xu et al. 2008). Most of the pathogenic variants span many genes, but smaller variants are emerging and are pinpointing specific genes, for example Neurexin 1 (Kirov et al. 2009b; Pinto et al. 2010; Rujescu et al. 2009).

Some CNVs found in SCZ and bipolar disorder are also detected in individuals affected by neurodevelopmental disorders, such as Intellectual Disability/Developmental Delay (ID/DD), ASD, Attention Deficit Hyperactivity Disorder (ADHD) and epilepsy. For example, the "chromosome 3 q29 deletion syndrome" (MIM609424), discovered in a cohort of patients with ID/DD and minor facial dysmorphisms, was later associated with ASD, bipolar disorder and depression/anxiety 
(Quintero-Rivera et al. 2010). The genes and molecular pathways shared between these conditions are supporting the concept that psychiatric disorders have also a neurodevelopmental origin.

Here, we report a four-generation family segregating a 3q29 deletion proximal to the known 3q29 deletion/duplication syndrome, which presents with a variable neuropsychiatric phenotype including ASD, ID and SCZ, obesity and frequent ophthalmological disturbances.

\section{MATERIALS AND METHODS}

\section{Patients and genomic DNA extraction}

Clinical information from all patients involved in the study was collected by experienced psychiatrists and clinical geneticists. Informed consent was obtained from patients or their legal representative. Genomic DNA was extracted from peripheral blood using the QIAamp DSP DNA Blood Mini Kit (Qiagen, Hilden, Germany) following the manufacturer's instructions. DNA quality was assessed using NanoDrop 1000 Spectrophotometer (ThermoScientific, Wilmington, DE, U.S.A.).

\section{Molecular analyses}

Array-CGH was performed using a 44K whole-genome oligonucleotide microarray following the manufacturer's protocol (Agilent Technologies, Santa Clara, California, USA). Briefly, 500 ng of genomic DNA was digested with AluI and RsaI and labelled with cyanine 3-dUTP (proband) cyanine 5-dUTP (control subject). Pooled DNAs were denatured and hybridized on the macroarray for 24 hours at $65^{\circ} \mathrm{C}$. Slides were washed and scanned using a G2565BA scanner, and analyzed using Agilent CGH Analytics software ver. 4.0.81 (Agilent Technologies Inc.) with the statistical algorithm ADM-2 and a sensitivity threshold of 6.0. Significant copy number changes were identified by at least three consecutive aberrant probes. The pathogenicity of the CNVs identified by array-CGH was evaluated based on the findings in the Database of Genomic Variants (DGV, http://projects.tcag.ca/variation), the ClinVar (http://www.ncbi.nlm.nih.gov/clinvar/) and the 
Database of Chromosomal Imbalance and Phenotype in Humans using Ensemble Resources (DECIPHER, https://decipher.sanger.ac.uk/application/).

Real-time quantitative PCR was performed to confirm array-CGH data. We designed a set of primers and probes specific for exon 30 of $O P A 1$ gene (ref seq NM_130837) using the Roche Diagnostics Universal probe Library software (http://www.universalprobelibrary.com). Amplification was performed in a total volume of $20 \mu \mathrm{l}$ containing $2 \mathrm{X}$ TaqMan Universal PCR Master mix (P/N 4324018, Life Technologies, CA, USA), 1X RNaseP assay (20X, VIC dye), 0.2 $\mu \mathrm{M}$ of forward (5'- cgttaggctttctgttaatagtggt $\left.-3^{\prime}\right)$ and reverse (5'- tgtcataatccggtggctct - 3') primers and $0.1 \mu \mathrm{M}$ UPL probe \#2. Each sample was run in triplicate using the following protocol: $2 \mathrm{~min}$ at $50^{\circ} \mathrm{C}, 10 \mathrm{~min}$ at $95^{\circ} \mathrm{C}$, followed by 40 cycles $15 \mathrm{sec} 95^{\circ} \mathrm{C}$ and $1 \mathrm{~min} 60^{\circ} \mathrm{C}$. The PCR was performed on a 7500 fast apparatus (Life Technologies). The copy number was calculated using the comparative delta $\mathrm{Ct}$ method.

\section{RESULTS}

\section{Clinical description}

The proband was a 3 year old girl referred to the Pediatrics Genetic Unit for severe DD and ASD. Pregnancy was reported as normal, except for a positive Wald test; fetal karyotype performed on chorionic villus sampling was normal $(46, \mathrm{XX})$. She was born by spontaneous delivery at term; birth weight was $3,120 \mathrm{gr}\left(25^{\text {th }}\right.$ centile $)$, length $50 \mathrm{~cm}\left(50^{\text {th }}\right.$ centile $)$, OFC $35 \mathrm{~cm}\left(75^{\text {th }}\right.$ centile $)$, and APGAR scores 9/10. She suffered from gastroesophageal reflux and milk protein intolerance since the first months of life. She reached motor milestones within expected range (independent walking 14 months). She was initially referred to the Neuropsychiatric Service for language delay at the age of 30 months. After further evaluation with ADOS, CARS and Vineland Adaptive Behavior scales, the patient was diagnosed with severe autism accompanied with cognitive delay (ADOS module 1: communication score 9, reciprocal social interaction score 12; CARS score 39; Vineland Adaptive Behavior scale: age-equivalent score 20 months versus chronological age of 4 years). Brain MRI, 
EEG, tonal audiometry, standard karyotype and FRAXA testing were all normal. On clinical examination, she showed no evident facial dysmorphisms and a normal growth pattern (weight 14 $\mathrm{kg}, 50^{\text {th }}$ centile, height $95 \mathrm{~cm}, 50^{\text {th }}$ centile, OFC $48.5 \mathrm{~cm}, 25^{\text {th }}$ centile). Cardiological exams and thyroid function were normal. The patient was included in a protocol for clinical follow-up, and we performed array-CGH analysis (see molecular data below).

At the last clinical evaluation (9-year old), she showed severe cognitive delay (Griffith scale total quotient $=34$ ), motor stereotypies and bruxism; language was absent and she communicated by Augmentative and Alternative Communication. She also showed infantile obesity (weight $53 \mathrm{~kg}$, height $138 \mathrm{~cm}$, BMI 27.8) with acanthosis nigricans on the neck and armpits. Parents reported selective eating with no hyperphagia, constipation, nocturnal awakenings and occasional selfinjuries.

Family history was remarkable for psychiatric and ophthalmologic disorders (Figure 1 and table I). Two maternal aunts and a brother of the maternal grandmother were institutionalized for schizophrenia (III-4 undifferentiated schizophrenia, III-5 paranoid schizophrenia, II-3 schizoaffective disorder). The mother (subject III-6) had experienced an episode of major depression and suffered from anxiety disorder. Anxiety disorder was reported also for the greatgrandmother (subject I-2). Formal neuropsychiatric evaluation indicated ASD, social anxiety and borderline personality disorder in subject III-1, and dysthymia, avoidant personality disorder and microcephaly in subject II-2. Learning disabilities were reported for patients II-3 and III-4 and both had not completed the lower secondary school.

Evaluation of non-carriers (subjects III-2 and III-3) indicated no cognitive or psychiatric disorder. Another consistent phenotype was overweight/obesity, which was present in all carriers of the deletion but not in non-carriers (Table I).

Since the deletion spans $O P A 1$, a gene associated with an autosomal dominant syndromic form of optic atrophy (MIM\#165500) (see molecular data below), we performed a formal ophthalmologic 
and audiological examination in four subjects (II-2, III-1, III-6 and IV-2). Given the profound behavioral disturbances of proband (IV-2), we were able to assess solely the auditory brainstem response (ABR) and fundus oculi and both were normal. The three remaining subjects underwent a complete ophthalmological evaluation, including visual acuity, visual field testing with Humphrey Field Analyzer (HFA), Visual Evoked Cortical Potentials (VECPs), contrast sensitivity, retinal Optical Coherence Tomography (OCT), analysis of optic nerve with the Glaucoma Diagnosis instrument (scanning laser polarimeter; GDx) and OCT nerve fiber layer, Cup-to-Disc (CD) ratio. We detected in all patients an optic disc pallor involving the temporal area with cup to disc ratio > 0.5, a feature observed in $50 \%$ of patients with dominant optic atrophy (Votruba et al. 2003), and associated with OCT nerve fiber layer borderline to lower than normal in II-2 and III-6. Audiometry measures were normal in all subjects (II-2, III-1 and III-6).

\section{Molecular analyses}

Array-CGH analysis identified a 1.36 Mb deletion on chromosome 3q29 (position 193,046,853194,407,385, assembly GRCh17/hg19) encompassing 10 RefSeq coding-genes: ATP13A4, OPA1, HES1, CPN2, GP5, LRRC15, ATP13A3, TMEM44, FAM34A and LSG1. To validate the deletion identified by array-CGH, we performed real-time qPCR in all available subjects of the family (Fig. 1B). The deletion was inherited from the mother (III-6), and was present in the maternal uncle (III1), two maternal aunts (III-4), the maternal grandmother (II-2), and her brother (II-3).

Using the online databases (ClinVar, Database of Genomic Variants, DECIPHER, Ecauruca and PubMed), we found other cases with syndromic ID/DD that overlap with the deleted region we identified: six large deletions (two from DECIPHER, each of 9 Mb: 256994 and 4430, and four from ClinVar: nssv577933, nssv577935, nssv582956 and nssv1494859) and fifteen large duplications (two from DECIPHER: 252539, 249410, and thirteen from ClinVar: nssv584484, nssv578943, nssv578945, nssv578946, nssv578949, nssv578951， nssv578952， nssv578953, nssv578954, nssv578955, nssv582491, nssv1494856 and nssv1494861). 


\section{DISCUSSION}

The 3q29 microdeletion syndrome is a recurrent subtelomeric 1.3-1.6 Mb deletion, which encompasses more than 20 protein-coding genes (Willatt et al. 2005). Its variable clinical manifestations include intellectual deficit and/or learning disabilities with speech delay and mild dysmorphic features (Cox and Butler 2015; Digilio et al. 2009; Willatt et al. 2005). This deletion and its duplication counterpart belong to a growing group of $\mathrm{CNVs}$ associated both with psychiatric disorders and ID/DD. Indeed, a recent meta-analysis showed a 41.1-fold increased risk for SCZ, showing that the 3q29 deletion may be the single largest risk factor for SCZ, exceeding even the 22q11.2 deletion (Mulle 2015). Three genes, FBXO45 (MIM 609112), DLG1 (MIM 601014), and PAK2 (MIM 605022), have been proposed as causative of the psychiatric manifestations, because they play putative roles in synaptic transmission (Quintero-Rivera et al. 2010).

We identified a $1.36 \mathrm{Mb}$ deletion centromeric to this region, and showed that is also associated with ASD, ID/DD, psychiatric traits with variable expressivity, as well as with overweight/obesity. Similar to the 3q29 microdeletion syndrome, the familial deletion we identified manifests with heterogeneity in the neuropsychiatric phenotype. The rearrangement segregated from the mother, affected by anxiety disorder and major depression, and was present in five additional family members, all displaying psychiatric disturbances, such as schizophrenia, anxiety and personality disorders. The father and three other members of the maternal family did not show psychiatric traits and did not carry the deletion. Two carriers of the deletion were diagnosed with ASD: the child proband (IV-2) and an adult (III-1). The observation that the adult ASD patient has borderline personality disorder and social anxiety in comorbidity) raises the intriguing possibility that the $3 q 29$ deletion might undergo a phenotypic transition during development, as documented for patients with the 22q11.2 deletion syndrome (Swillen and McDonald-McGinn 2015). Longitudinal followup of the proband will help elucidating the developmental trajectory of the 3q29 proximal deletion. 
An alternative hypothesis is variable intra-familial expressivity. A shared basis for SCZ and ASD has been suggest almost half a century ago (Ornitz 1969), and is supported by similar neuropsychological profiles (e.g., Theory of mind and mirror neuron function deficits) (BaronCohen et al. 1985; Enticott et al. 2008; Lysaker et al. 2011; Rizzolatti and Craighero 2004; Rizzolatti and Fabbri-Destro 2010), alterations in brain cytoarchitecture al organization (e.g., proliferation, migration and lamination defects) (de Lacy and King 2013), neuroimaging patterns (Avino and Hutsler 2010; Baribeau and Anagnostou 2013; Cauda et al. 2014; Cauda et al. 2011; Cheung et al. 2010; Eastwood and Harrison 2003; Mueller et al. 2012; Venkataraman et al. 2012; Walterfang et al. 2008), and genetic overlap (Cross-Disorder Group of the Psychiatric Genomics et al. 2013; De Rubeis et al. 2014; Fromer et al. 2014). SCZ and high functioning ASD show a high degree of clinical convergence, particularly in SCZ cases with negative symptoms, and differential diagnosis requires experienced skills (Keller 2015; Luciano et al. 2014; Spek et al. 2010). Mild neurological signs in Asperger's syndrome are not different from early-onset psychosis (Mayoral et al. 2010) and an overlap of autistic and schizotypal traits in adolescence has been described (Barneveld et al. 2011). Both may share cognitive impairment, and motor symptoms, including catatonia (Nylander et al. 2013). Some autistic subjects develop a clinical course indistinguishable from SCZ in adolescence and, on the other hand, childhood onset schizophrenia is preceded by and comorbid with ASD in 30\%-50\% of cases (Rapoport et al. 2009). Anxiety disorders are also frequent in ASD (Mazefsky et al. 2008). Finally, genes with de novo mutations in SCZ overlap with those mutated in ASD (De Rubeis et al. 2014; Fromer et al. 2014) and ASD and SCZ share risk genes important brain development and physiology, e.g., SHANK3 (Bozdagi et al. 2010; Kozol et al. 2015), SCN2A (Gazina et al. 2015; Hu et al. 2009), NRXN1 (Sudhof 2008), and RELN (D'Arcangelo et al. 1995). 
The 3q29 proximal deletion syndrome here described may link the phenotypic psychotic dimension (schizophrenic spectrum disorder), the avoidant dimension (anxiety, social phobia, avoidant personality) and ASD.

Among the genes spanned by the deletion, only OPAl mutations cause a Mendelian disorder, the autosomal dominant optic atrophy type 1, and its haploinsufficiency explains the typical profile with bilateral symmetrical thinning around the optic disc, most pronounced in the temporal quadrant (Hudson et al. 2008), observed in the 3q29 proximal deletion carriers. This feature is consistent with the retinal ganglion cell atrophy typical for $O P A 1$ deletion, and it co-occurred with abnormal contrast sensitivity indicative of optic nerve dysfunction. The visual field, another index of optic nerve dysfunction, did not have extensive damage.

The neuropsychiatric and cognitive phenotype likely resulted from the haploinsufficiency of ATP13A4 and/or HES1. ATP13A4 (MIM609556) encodes a cation transporter ATPase of the P5 family and was reported as disrupted by an inversion in a female with specific language impairment having significant deficits in both expressive and receptive language abilities but intact cognitive function (Kwasnicka-Crawford et al. 2005). The inversion was inherited from her father, who was also language delayed (Kwasnicka-Crawford et al. 2005). Our patient is not verbal. The behavioral phenotype of the patient with the inversion is milder that the one we observed: she had delayed expressive and receptive language and exhibited some difficulties in communication and social interaction, but did not show stereotyped behaviors or restricted interests. She was not classified on the autism spectrum. A mutational screening also detected a missense variant (p.Glu646Asp) in 6 out of 32 individuals affected by ASD, although the pathogenicity of this variant remains unclear (Kwasnicka-Crawford et al. 2005). The neuronal functions of ATP13A4 have not been investigated yet, but ATP13A4 expression in mouse brain increases during neurogenesis suggesting that it might be critical in early neuronal development (Vallipuram et al. 2010; Weingarten et al. 2012). Overexpressing ATP13A4 in a cell line causes an increase in intracellular calcium, and the 
p.Glu646Asp amino acid change identified in subjects with ASD suppresses such affect (Vallipuram et al. 2010). These data suggests that ATP13A4 might regulate calcium homeostasis. Noteworthy, calcium channels and regulators of calcium homeostasis have been repeatedly implicated in ASD, ID and schizophrenia (De Rubeis et al. 2014; Endele et al. 2010; Purcell et al. 2014; Ripke et al. 2013; Splawski et al. 2004). Interestingly, another P5 ATPases is encompassed by the 3q29 deletions we identified (ATP13A3), but no evidence supports a role for this gene in ASD or other psychiatric conditions. Recently, a de novo 3q29 duplication partially overlapping with the region in the $3 \mathrm{q} 29$ proximal deletion in a patient with oculo auriculo vertebral spectrum (OAVS, OMIM 164210) was reported and ATP13A3 suggested as candidate gene (Guida et al. 2015).

A second gene within the deleted region, Hairy/Enhancer of Split Drosophila homolog 1 (HES1; MIM*139605), was shown to be involved in neuronal migration, oligodendrocytes maturation, and in cochlear neuroepithelium proliferation (Aujla et al. 2011; Ogata et al. 2011; Tateya et al. 2011). HES1 has been suggested to be a candidate for ASD by association studies (de Krom et al. 2009; Lasky-Su et al. 2008), and might represent a promising candidate gene for the neuropsychiatric phenotype observed in the family. We speculate that mutations in ATP13A4 or HES1 may associate with a psychiatric phenotype, suggesting a screening among patients with psychiatric disorders.

Several observations indicate that HES1 plays a complex role in the regulation of metabolism. HES1 is a downstream target of Notch and mediates preadipocytes differentiation in white adipocytes (Bi et al. 2014), indicating that HES1 loss or downregulation might reduce white adipocytes differentiation and thus prevent weight gain. However, decreased hepatic expression of HES1 underlies hepatic steatosis (Lemke et al. 2008), which is intimately associated with obesity. Furthermore, HES1 regulates the maintenance and differentiation of neuronal progenitors of the hypothalamic arcuate nucleus, which contributes to regulate feeding, energy balance and body size: mice lacking a critical co-factor of Notch and regulator of HES1 have abolished HES1 expression and show increased body weight (Aujla et al. 2013). The latter evidence supports the hypothesis 
that the overweight/obesity phenotype associated with the 3q29 proximal deletion might be due to altered development of the arcuate nucleus resulting from HES1 haploinsufficiency.

We cannot exclude that the deletion here described is causing a "position effect", with a mechanism known as enhancer adoption. We recently showed this mechanism may cause a rare neurodegenerative disease, disrupting regulatory boundary elements (Giorgio et al. 2015). Indeed, almost $12 \%$ of the deletions reported in Decipher are best explained by enhancer adoption or a combination of enhancer adoption and gene-dosage effects. In analogy, we can take in consideration that the two nearby deletions in 3q29 may share a common genetic mechanism .as recently demonstrated for other copy number variations (Ibn-Salem et al. 2014).

In conclusion, our data suggest a novel contiguous gene syndrome with optic nerve atrophy due to $O P A 1$ and neuropsychiatric features associated with overweight/obesity associated with ATP13A4 or/and HES1.

\section{ACKNOWLEDGMENTS}

The authors declare no conflict of interest. This work was funded by MURST $60 \%$ (to A. Brusco). This study utilizes data generated by the DECIPHER Consortium. A full list of centers who contributed to the generation of the data is available from http://decipher.sanger.ac.uk and via email from decipher@sanger.ac.uk; funding for the project was provided by the Wellcome Trust. S.D.R. is a Seaver Postdoctoral Fellow. 


\section{REFERENCES}

Aujla PK, Bora A, Monahan P, Sweedler JV, Raetzman LT. 2011. The Notch effector gene Hes1 regulates migration of hypothalamic neurons, neuropeptide content and axon targeting to the pituitary. Dev Biol 353(1):61-71.

Aujla PK, Naratadam GT, Xu L, Raetzman LT. 2013. Notch/Rbpjkappa signaling regulates progenitor maintenance and differentiation of hypothalamic arcuate neurons. Development 140(17):3511-3521.

Avino TA, Hutsler JJ. 2010. Abnormal cell patterning at the cortical gray-white matter boundary in autism spectrum disorders. Brain Res 1360:138-146.

Baribeau DA, Anagnostou E. 2013. A comparison of neuroimaging findings in childhood onset schizophrenia and autism spectrum disorder: a review of the literature. Front Psychiatry $4: 175$.

Barneveld PS, Pieterse J, de Sonneville L, van Rijn S, Lahuis B, van Engeland H, Swaab H. 2011. Overlap of autistic and schizotypal traits in adolescents with Autism Spectrum Disorders. Schizophrenia research 126(1-3):231-236.

Baron-Cohen S, Leslie AM, Frith U. 1985. Does the autistic child have a "theory of mind"? Cognition 21(1):37-46.

Bi P, Shan T, Liu W, Yue F, Yang X, Liang XR, Wang J, Li J, Carlesso N, Liu X, Kuang S. 2014. Inhibition of Notch signaling promotes browning of white adipose tissue and ameliorates obesity. Nat Med 20(8):911-918.

Bozdagi O, Sakurai T, Papapetrou D, Wang X, Dickstein DL, Takahashi N, Kajiwara Y, Yang M, Katz AM, Scattoni ML, Harris MJ, Saxena R, Silverman JL, Crawley JN, Zhou Q, Hof PR, Buxbaum JD. 2010. Haploinsufficiency of the autism-associated Shank3 gene leads to deficits in synaptic function, social interaction, and social communication. Molecular autism 1(1): 15 .

Cauda F, Costa T, Palermo S, D'Agata F, Diano M, Bianco F, Duca S, Keller R. 2014. Concordance of white matter and gray matter abnormalities in autism spectrum disorders: a voxel-based meta-analysis study. Hum Brain Mapp 35(5):2073-2098.

Cauda F, Geda E, Sacco K, D'Agata F, Duca S, Geminiani G, Keller R. 2011. Grey matter abnormality in autism spectrum disorder: an activation likelihood estimation meta-analysis study. Journal of neurology, neurosurgery, and psychiatry 82(12):1304-1313.

Cheung C, Yu K, Fung G, Leung M, Wong C, Li Q, Sham P, Chua S, McAlonan G. 2010. Autistic disorders and schizophrenia: related or remote? An anatomical likelihood estimation. PLoS One 5(8):e12233.

Cox DM, Butler MG. 2015. A clinical case report and literature review of the 3q29 microdeletion syndrome. Clin Dysmorphol 24(3):89-94.

Cross-Disorder Group of the Psychiatric Genomics C, Lee SH, Ripke S, Neale BM, Faraone SV, Purcell SM, Perlis RH, Mowry BJ, Thapar A, Goddard ME, Witte JS, Absher D, Agartz I, Akil H, Amin F, Andreassen OA, Anjorin A, Anney R, Anttila V, Arking DE, Asherson P, Azevedo MH, Backlund L, Badner JA, Bailey AJ, Banaschewski T, Barchas JD, Barnes MR, Barrett TB, Bass N, Battaglia A, Bauer M, Bayes M, Bellivier F, Bergen SE, Berrettini W, Betancur C, Bettecken T, Biederman J, Binder EB, Black DW, Blackwood DH, Bloss CS, Boehnke M, Boomsma DI, Breen G, Breuer R, Bruggeman R, Cormican P, Buccola NG, Buitelaar JK, Bunney WE, Buxbaum JD, Byerley WF, Byrne EM, Caesar S, Cahn W, Cantor RM, Casas M, Chakravarti A, Chambert K, Choudhury K, Cichon S, Cloninger CR, Collier DA, Cook EH, Coon H, Cormand B, Corvin A, Coryell WH, Craig DW, Craig IW, Crosbie J, Cuccaro ML, Curtis D, Czamara D, Datta S, Dawson G, Day R, De Geus EJ, Degenhardt F, Djurovic S, Donohoe GJ, Doyle AE, Duan J, Dudbridge F, Duketis E, Ebstein RP, Edenberg HJ, Elia J, Ennis S, Etain B, Fanous A, Farmer AE, Ferrier IN, Flickinger M, Fombonne E, Foroud T, Frank J, Franke B, Fraser C, Freedman R, Freimer 
NB, Freitag CM, Friedl M, Frisen L, Gallagher L, Gejman PV, Georgieva L, Gershon ES, Geschwind DH, Giegling I, Gill M, Gordon SD, Gordon-Smith K, Green EK, Greenwood TA, Grice DE, Gross M, Grozeva D, Guan W, Gurling H, De Haan L, Haines JL, Hakonarson H, Hallmayer J, Hamilton SP, Hamshere ML, Hansen TF, Hartmann AM, Hautzinger M, Heath AC, Henders AK, Herms S, Hickie IB, Hipolito M, Hoefels S, Holmans PA, Holsboer F, Hoogendijk WJ, Hottenga JJ, Hultman CM, Hus V, Ingason A, Ising M, Jamain S, Jones EG, Jones I, Jones L, Tzeng JY, Kahler AK, Kahn RS,

Kandaswamy R, Keller MC, Kennedy JL, Kenny E, Kent L, Kim Y, Kirov GK, Klauck SM, Klei L, Knowles JA, Kohli MA, Koller DL, Konte B, Korszun A, Krabbendam L, Krasucki R, Kuntsi J, Kwan P, Landen M, Langstrom N, Lathrop M, Lawrence J, Lawson WB, Leboyer M, Ledbetter DH, Lee PH, Lencz T, Lesch KP, Levinson DF, Lewis CM, Li J, Lichtenstein P, Lieberman JA, Lin DY, Linszen DH, Liu C, Lohoff FW, Loo SK, Lord C, Lowe JK, Lucae S, MacIntyre DJ, Madden PA, Maestrini E, Magnusson PK, Mahon PB, Maier W, Malhotra AK, Mane SM, Martin CL, Martin NG, Mattheisen M, Matthews K, Mattingsdal M, McCarroll SA, McGhee KA, McGough JJ, McGrath PJ, McGuffin P, McInnis MG, McIntosh A, McKinney R, McLean AW, McMahon FJ, McMahon WM, McQuillin A, Medeiros H, Medland SE, Meier S, Melle I, Meng F, Meyer J, Middeldorp CM, Middleton L, Milanova V, Miranda A, Monaco AP, Montgomery GW, Moran JL, Moreno-De-Luca D, Morken G, Morris DW, Morrow EM, Moskvina V, Muglia P, Muhleisen TW, Muir WJ, Muller-Myhsok B, Murtha M, Myers RM, Myin-Germeys I, Neale MC, Nelson SF, Nievergelt CM, Nikolov I, Nimgaonkar V, Nolen WA, Nothen MM, Nurnberger JI, Nwulia EA, Nyholt DR, O'Dushlaine C, Oades RD, Olincy A, Oliveira G, Olsen L, Ophoff RA, Osby U, Owen MJ, Palotie A, Parr JR, Paterson AD, Pato CN, Pato MT, Penninx BW, Pergadia ML, Pericak-Vance MA, Pickard BS, Pimm J, Piven J, Posthuma D, Potash JB, Poustka F, Propping P, Puri V, Quested DJ, Quinn EM, RamosQuiroga JA, Rasmussen HB, Raychaudhuri S, Rehnstrom K, Reif A, Ribases M, Rice JP, Rietschel M, Roeder K, Roeyers H, Rossin L, Rothenberger A, Rouleau G, Ruderfer D, Rujescu D, Sanders AR, Sanders SJ, Santangelo SL, Sergeant JA, Schachar R, Schalling M, Schatzberg AF, Scheftner WA, Schellenberg GD, Scherer SW, Schork NJ, Schulze TG, Schumacher J, Schwarz M, Scolnick E, Scott LJ, Shi J, Shilling PD, Shyn SI, Silverman JM, Slager SL, Smalley SL, Smit JH, Smith EN, Sonuga-Barke EJ, St Clair D, State M, Steffens M, Steinhausen HC, Strauss JS, Strohmaier J, Stroup TS, Sutcliffe JS, Szatmari P, Szelinger S, Thirumalai S, Thompson RC, Todorov AA, Tozzi F, Treutlein J, Uhr M, van den Oord EJ, Van Grootheest G, Van Os J, Vicente AM, Vieland VJ, Vincent JB, Visscher PM, Walsh CA, Wassink TH, Watson SJ, Weissman MM, Werge T, Wienker TF, Wijsman EM, Willemsen G, Williams N, Willsey AJ, Witt SH, Xu W, Young AH, Yu TW, Zammit S, Zandi PP, Zhang P, Zitman FG, Zollner S, International Inflammatory Bowel Disease Genetics C, Devlin B, Kelsoe JR, Sklar P, Daly MJ, O'Donovan MC, Craddock N, Sullivan PF, Smoller JW, Kendler KS, Wray NR. 2013. Genetic relationship between five psychiatric disorders estimated from genome-wide SNPs. Nat Genet 45(9):984-994.

D'Arcangelo G, Miao GG, Chen SC, Soares HD, Morgan JI, Curran T. 1995. A protein related to extracellular matrix proteins deleted in the mouse mutant reeler. Nature 374(6524):719-723.

de Krom M, Staal WG, Ophoff RA, Hendriks J, Buitelaar J, Franke B, de Jonge MV, Bolton P, Collier D, Curran S, van Engeland H, van Ree JM. 2009. A common variant in DRD3 receptor is associated with autism spectrum disorder. Biol Psychiatry 65(7):625-630.

de Lacy N, King BH. 2013. Revisiting the relationship between autism and schizophrenia: toward an integrated neurobiology. Annual review of clinical psychology 9:555-587.

De Rubeis S, He X, Goldberg AP, Poultney CS, Samocha K, Cicek AE, Kou Y, Liu L, Fromer M, Walker S, Singh T, Klei L, Kosmicki J, Shih-Chen F, Aleksic B, Biscaldi M, Bolton PF, Brownfeld JM, Cai J, Campbell NG, Carracedo A, Chahrour MH, Chiocchetti AG, Coon H, Crawford EL, Curran SR, Dawson G, Duketis E, Fernandez BA, Gallagher L, Geller E, 
Guter SJ, Hill RS, Ionita-Laza J, Jimenz Gonzalez P, Kilpinen H, Klauck SM, Kolevzon A, Lee I, Lei I, Lei J, Lehtimaki T, Lin CF, Ma'ayan A, Marshall CR, McInnes AL, Neale B, Owen MJ, Ozaki N, Parellada M, Parr JR, Purcell S, Puura K, Rajagopalan D, Rehnstrom K, Reichenberg A, Sabo A, Sachse M, Sanders SJ, Schafer C, Schulte-Ruther M, Skuse D, Stevens C, Szatmari P, Tammimies K, Valladares O, Voran A, Li-San W, Weiss LA, Willsey AJ, Yu TW, Yuen RK, Study DDD, Homozygosity Mapping Collaborative for A, Consortium UK, Cook EH, Freitag CM, Gill M, Hultman CM, Lehner T, Palotie A, Schellenberg GD, Sklar P, State MW, Sutcliffe JS, Walsh CA, Scherer SW, Zwick ME, Barett JC, Cutler DJ, Roeder K, Devlin B, Daly MJ, Buxbaum JD. 2014. Synaptic, transcriptional and chromatin genes disrupted in autism. Nature 515(7526):209-215.

Digilio MC, Bernardini L, Mingarelli R, Capolino R, Capalbo A, Giuffrida MG, Versacci P, Novelli A, Dallapiccola B. 2009. 3q29 Microdeletion: a mental retardation disorder unassociated with a recognizable phenotype in two mother-daughter pairs. Am J Med Genet A 149A(8):1777-1781.

Eastwood SL, Harrison PJ. 2003. Interstitial white matter neurons express less reelin and are abnormally distributed in schizophrenia: towards an integration of molecular and morphologic aspects of the neurodevelopmental hypothesis. Mol Psychiatry 8(9):769, 821731.

Endele S, Rosenberger G, Geider K, Popp B, Tamer C, Stefanova I, Milh M, Kortum F, Fritsch A, Pientka FK, Hellenbroich Y, Kalscheuer VM, Kohlhase J, Moog U, Rappold G, Rauch A, Ropers HH, von Spiczak S, Tonnies H, Villeneuve N, Villard L, Zabel B, Zenker M, Laube B, Reis A, Wieczorek D, Van Maldergem L, Kutsche K. 2010. Mutations in GRIN2A and GRIN2B encoding regulatory subunits of NMDA receptors cause variable neurodevelopmental phenotypes. Nat Genet 42(11):1021-1026.

Enticott PG, Hoy KE, Herring SE, Johnston PJ, Daskalakis ZJ, Fitzgerald PB. 2008. Reduced motor facilitation during action observation in schizophrenia: a mirror neuron deficit? Schizophrenia research 102(1-3):116-121.

Fromer M, Pocklington AJ, Kavanagh DH, Williams HJ, Dwyer S, Gormley P, Georgieva L, Rees E, Palta P, Ruderfer DM, Carrera N, Humphreys I, Johnson JS, Roussos P, Barker DD, Banks E, Milanova V, Grant SG, Hannon E, Rose SA, Chambert K, Mahajan M, Scolnick EM, Moran JL, Kirov G, Palotie A, McCarroll SA, Holmans P, Sklar P, Owen MJ, Purcell SM, O'Donovan MC. 2014. De novo mutations in schizophrenia implicate synaptic networks. Nature 506(7487):179-184.

Gazina EV, Leaw BT, Richards KL, Wimmer VC, Kim TH, Aumann TD, Featherby TJ, Churilov L, Hammond VE, Reid CA, Petrou S. 2015. 'Neonatal' Nav1.2 reduces neuronal excitability and affects seizure susceptibility and behaviour. Hum Mol Genet 24(5):1457-1468.

Giorgio E, Robyr D, Spielmann M, Ferrero E, Di Gregorio E, Imperiale D, Vaula G, Stamoulis G, Santoni F, Atzori C, Gasparini L, Ferrera D, Canale C, Guipponi M, Pennacchio LA, Antonarakis SE, Brussino A, Brusco A. 2015. A large genomic deletion leads to enhancer adoption by the lamin $\mathrm{B} 1$ gene: a second path to autosomal dominant adult-onset demyelinating leukodystrophy (ADLD). Hum Mol Genet 24(11):3143-3154.

Green EK, Rees E, Walters JT, Smith KG, Forty L, Grozeva D, Moran JL, Sklar P, Ripke S, Chambert KD, Genovese G, McCarroll SA, Jones I, Jones L, Owen MJ, O'Donovan MC, Craddock N, Kirov G. 2015. Copy number variation in bipolar disorder. Mol Psychiatry.

Guida V, Sinibaldi L, Pagnoni M, Bernardini L, Loddo S, Margiotti K, Digilio MC, Fadda MT, Dallapiccola B, Iannetti G, Alessandro de L. 2015. A de novo proximal 3q29 chromosome microduplication in a patient with oculo auriculo vertebral spectrum. Am J Med Genet A 167A(4):797-801.

$\mathrm{Hu}$ W, Tian C, Li T, Yang M, Hou H, Shu Y. 2009. Distinct contributions of Na(v)1.6 and Na(v)1.2 in action potential initiation and backpropagation. Nat Neurosci 12(8):996-1002. 
Hudson G, Amati-Bonneau P, Blakely EL, Stewart JD, He L, Schaefer AM, Griffiths PG, Ahlqvist K, Suomalainen A, Reynier P, McFarland R, Turnbull DM, Chinnery PF, Taylor RW. 2008. Mutation of OPA1 causes dominant optic atrophy with external ophthalmoplegia, ataxia, deafness and multiple mitochondrial DNA deletions: a novel disorder of mtDNA maintenance. Brain 131(Pt 2):329-337.

Ibn-Salem J, Kohler S, Love MI, Chung HR, Huang N, Hurles ME, Haendel M, Washington NL, Smedley D, Mungall CJ, Lewis SE, Ott CE, Bauer S, Schofield PN, Mundlos S, Spielmann M, Robinson PN. 2014. Deletions of chromosomal regulatory boundaries are associated with congenital disease. Genome biology 15(9):423.

International Schizophrenia C. 2008. Rare chromosomal deletions and duplications increase risk of schizophrenia. Nature 455(7210):237-241.

Jacquemont S, Reymond A, Zufferey F, Harewood L, Walters RG, Kutalik Z, Martinet D, Shen Y, Valsesia A, Beckmann ND, Thorleifsson G, Belfiore M, Bouquillon S, Campion D, de Leeuw N, de Vries BB, Esko T, Fernandez BA, Fernandez-Aranda F, Fernandez-Real JM, Gratacos M, Guilmatre A, Hoyer J, Jarvelin MR, Kooy RF, Kurg A, Le Caignec C, Mannik K, Platt OS, Sanlaville D, Van Haelst MM, Villatoro Gomez S, Walha F, Wu BL, Yu Y, Aboura A, Addor MC, Alembik Y, Antonarakis SE, Arveiler B, Barth M, Bednarek N, Bena F, Bergmann S, Beri M, Bernardini L, Blaumeiser B, Bonneau D, Bottani A, Boute O, Brunner HG, Cailley D, Callier P, Chiesa J, Chrast J, Coin L, Coutton C, Cuisset JM, Cuvellier JC, David A, de Freminville B, Delobel B, Delrue MA, Demeer B, Descamps D, Didelot G, Dieterich K, Disciglio V, Doco-Fenzy M, Drunat S, Duban-Bedu B, Dubourg C, El-Sayed Moustafa JS, Elliott P, Faas BH, Faivre L, Faudet A, Fellmann F, Ferrarini A, Fisher R, Flori E, Forer L, Gaillard D, Gerard M, Gieger C, Gimelli S, Gimelli G, Grabe HJ, Guichet A, Guillin O, Hartikainen AL, Heron D, Hippolyte L, Holder M, Homuth G, Isidor B, Jaillard S, Jaros Z, Jimenez-Murcia S, Helas GJ, Jonveaux P, Kaksonen S, Keren B, Kloss-Brandstatter A, Knoers NV, Koolen DA, Kroisel PM, Kronenberg F, Labalme A, Landais E, Lapi E, Layet V, Legallic S, Leheup B, Leube B, Lewis S, Lucas J, MacDermot KD, Magnusson P, Marshall C, Mathieu-Dramard M, McCarthy MI, Meitinger T, Mencarelli MA, Merla G, Moerman A, Mooser V, Morice-Picard F, Mucciolo M, Nauck M, Ndiaye NC, Nordgren A, Pasquier L, Petit F, Pfundt R, Plessis G, Rajcan-Separovic E, Ramelli GP, Rauch A, Ravazzolo R, Reis A, Renieri A, Richart C, Ried JS, Rieubland C, Roberts W, Roetzer KM, Rooryck C, Rossi M, Saemundsen E, Satre V, Schurmann C, Sigurdsson E, Stavropoulos DJ, Stefansson H, Tengstrom C, Thorsteinsdottir U, Tinahones FJ, Touraine R, Vallee L, van Binsbergen E, Van der Aa N, Vincent-Delorme C, VisvikisSiest S, Vollenweider P, Volzke H, Vulto-van Silfhout AT, Waeber G, Wallgren-Pettersson C, Witwicki RM, Zwolinksi S, Andrieux J, Estivill X, Gusella JF, Gustafsson O, Metspalu A, Scherer SW, Stefansson K, Blakemore AI, Beckmann JS, Froguel P. 2011. Mirror extreme BMI phenotypes associated with gene dosage at the chromosome 16p11.2 locus. Nature 478(7367):97-102.

Keller RB, S.; Aresi, A.;, Notaro, L.; Bianco, F.; Pirfo, E. . 2015. Diagnosing Autism Spectrum Disorder in Adulthood. Journal Psychopathology(21):5.

Kirov G, Grozeva D, Norton N, Ivanov D, Mantripragada KK, Holmans P, International Schizophrenia C, Wellcome Trust Case Control C, Craddock N, Owen MJ, O'Donovan MC. 2009a. Support for the involvement of large copy number variants in the pathogenesis of schizophrenia. Hum Mol Genet 18(8):1497-1503.

Kirov G, Pocklington AJ, Holmans P, Ivanov D, Ikeda M, Ruderfer D, Moran J, Chambert K, Toncheva D, Georgieva L, Grozeva D, Fjodorova M, Wollerton R, Rees E, Nikolov I, van de Lagemaat LN, Bayes A, Fernandez E, Olason PI, Bottcher Y, Komiyama NH, Collins MO, Choudhary J, Stefansson K, Stefansson H, Grant SG, Purcell S, Sklar P, O'Donovan MC, Owen MJ. 2012. De novo CNV analysis implicates specific abnormalities of 
postsynaptic signalling complexes in the pathogenesis of schizophrenia. Mol Psychiatry 17(2):142-153.

Kirov G, Rujescu D, Ingason A, Collier DA, O'Donovan MC, Owen MJ. 2009b. Neurexin 1 (NRXN1) deletions in schizophrenia. Schizophr Bull 35(5):851-854.

Kozol RA, Cukier HN, Zou B, Mayo V, De Rubeis S, Cai G, Griswold AJ, Whitehead PL, Haines JL, Gilbert JR, Cuccaro ML, Martin ER, Baker JD, Buxbaum JD, Pericak-Vance MA, Dallman JE. 2015. Two knockdown models of the autism genes SYNGAP1 and SHANK3 in zebrafish produce similar behavioral phenotypes associated with embryonic disruptions of brain morphogenesis. Hum Mol Genet 24(14):4006-4023.

Kwasnicka-Crawford DA, Carson AR, Roberts W, Summers AM, Rehnstrom K, Jarvela I, Scherer SW. 2005. Characterization of a novel cation transporter ATPase gene (ATP13A4) interrupted by 3q25-q29 inversion in an individual with language delay. Genomics 86(2):182-194.

Lasky-Su J, Neale BM, Franke B, Anney RJ, Zhou K, Maller JB, Vasquez AA, Chen W, Asherson P, Buitelaar J, Banaschewski T, Ebstein R, Gill M, Miranda A, Mulas F, Oades RD, Roeyers H, Rothenberger A, Sergeant J, Sonuga-Barke E, Steinhausen HC, Taylor E, Daly M, Laird N, Lange C, Faraone SV. 2008. Genome-wide association scan of quantitative traits for attention deficit hyperactivity disorder identifies novel associations and confirms candidate gene associations. Am J Med Genet B Neuropsychiatr Genet 147B(8):1345-1354.

Lemke U, Krones-Herzig A, Berriel Diaz M, Narvekar P, Ziegler A, Vegiopoulos A, Cato AC, Bohl S, Klingmuller U, Screaton RA, Muller-Decker K, Kersten S, Herzig S. 2008. The glucocorticoid receptor controls hepatic dyslipidemia through Hes1. Cell Metab 8(3):212223.

Levinson DF, Duan J, Oh S, Wang K, Sanders AR, Shi J, Zhang N, Mowry BJ, Olincy A, Amin F, Cloninger CR, Silverman JM, Buccola NG, Byerley WF, Black DW, Kendler KS, Freedman R, Dudbridge F, Pe'er I, Hakonarson H, Bergen SE, Fanous AH, Holmans PA, Gejman PV. 2011. Copy number variants in schizophrenia: confirmation of five previous findings and new evidence for 3q29 microdeletions and VIPR2 duplications. Am J Psychiatry 168(3):302-316.

Levy D, Ronemus M, Yamrom B, Lee YH, Leotta A, Kendall J, Marks S, Lakshmi B, Pai D, Ye K, Buja A, Krieger A, Yoon S, Troge J, Rodgers L, Iossifov I, Wigler M. 2011. Rare de novo and transmitted copy-number variation in autistic spectrum disorders. Neuron 70(5):886897.

Luciano A, Bond GR, Drake RE. 2014. Does employment alter the course and outcome of schizophrenia and other severe mental illnesses? A systematic review of longitudinal research. Schizophr Res 159(2-3):312-321.

Lysaker PH, Olesek KL, Warman DM, Martin JM, Salzman AK, Nicolo G, Salvatore G, Dimaggio G. 2011. Metacognition in schizophrenia: correlates and stability of deficits in theory of mind and self-reflectivity. Psychiatry research 190(1):18-22.

Malhotra D, McCarthy S, Michaelson JJ, Vacic V, Burdick KE, Yoon S, Cichon S, Corvin A, Gary S, Gershon ES, Gill M, Karayiorgou M, Kelsoe JR, Krastoshevsky O, Krause V, Leibenluft E, Levy DL, Makarov V, Bhandari A, Malhotra AK, McMahon FJ, Nothen MM, Potash JB, Rietschel M, Schulze TG, Sebat J. 2011. High frequencies of de novo CNVs in bipolar disorder and schizophrenia. Neuron 72(6):951-963.

Marshall CR, Noor A, Vincent JB, Lionel AC, Feuk L, Skaug J, Shago M, Moessner R, Pinto D, Ren Y, Thiruvahindrapduram B, Fiebig A, Schreiber S, Friedman J, Ketelaars CE, Vos YJ, Ficicioglu C, Kirkpatrick S, Nicolson R, Sloman L, Summers A, Gibbons CA, Teebi A, Chitayat D, Weksberg R, Thompson A, Vardy C, Crosbie V, Luscombe S, Baatjes R, Zwaigenbaum L, Roberts W, Fernandez B, Szatmari P, Scherer SW. 2008. Structural variation of chromosomes in autism spectrum disorder. Am J Hum Genet 82(2):477-488. 
Mayoral M, Merchan-Naranjo J, Rapado M, Leiva M, Moreno C, Giraldez M, Arango C, Parellada M. 2010. Neurological soft signs in juvenile patients with Asperger syndrome, early-onset psychosis, and healthy controls. Early intervention in psychiatry 4(4):283-290.

Mazefsky CA, Folstein SE, Lainhart JE. 2008. Overrepresentation of mood and anxiety disorders in adults with autism and their first-degree relatives: what does it mean? Autism Res 1(3):193197.

McCarthy SE, Makarov V, Kirov G, Addington AM, McClellan J, Yoon S, Perkins DO, Dickel DE, Kusenda M, Krastoshevsky O, Krause V, Kumar RA, Grozeva D, Malhotra D, Walsh T, Zackai EH, Kaplan P, Ganesh J, Krantz ID, Spinner NB, Roccanova P, Bhandari A, Pavon K, Lakshmi B, Leotta A, Kendall J, Lee YH, Vacic V, Gary S, Iakoucheva LM, Crow TJ, Christian SL, Lieberman JA, Stroup TS, Lehtimaki T, Puura K, Haldeman-Englert C, Pearl J, Goodell M, Willour VL, Derosse P, Steele J, Kassem L, Wolff J, Chitkara N, McMahon FJ, Malhotra AK, Potash JB, Schulze TG, Nothen MM, Cichon S, Rietschel M, Leibenluft E, Kustanovich V, Lajonchere CM, Sutcliffe JS, Skuse D, Gill M, Gallagher L, Mendell NR, Wellcome Trust Case Control C, Craddock N, Owen MJ, O'Donovan MC, Shaikh TH, Susser E, Delisi LE, Sullivan PF, Deutsch CK, Rapoport J, Levy DL, King MC, Sebat J. 2009. Microduplications of 16p11.2 are associated with schizophrenia. Nat Genet 41(11):1223-1227.

Moreno-De-Luca D, Consortium S, Mulle JG, Simons Simplex Collection Genetics C, Kaminsky EB, Sanders SJ, GeneStar, Myers SM, Adam MP, Pakula AT, Eisenhauer NJ, Uhas K, Weik L, Guy L, Care ME, Morel CF, Boni C, Salbert BA, Chandrareddy A, Demmer LA, Chow EW, Surti U, Aradhya S, Pickering DL, Golden DM, Sanger WG, Aston E, Brothman AR, Gliem TJ, Thorland EC, Ackley T, Iyer R, Huang S, Barber JC, Crolla JA, Warren ST, Martin CL, Ledbetter DH. 2010. Deletion 17q12 is a recurrent copy number variant that confers high risk of autism and schizophrenia. Am J Hum Genet 87(5):618-630.

Mueller S, Keeser D, Reiser MF, Teipel S, Meindl T. 2012. Functional and structural MR imaging in neuropsychiatric disorders, part 2: application in schizophrenia and autism. AJNR Am J Neuroradiol 33(11):2033-2037.

Mulle JG. 2015. The 3q29 deletion confers $>40$-fold increase in risk for schizophrenia. Mol Psychiatry 20(9):1028-1029.

Mulle JG, Dodd AF, McGrath JA, Wolyniec PS, Mitchell AA, Shetty AC, Sobreira NL, Valle D, Rudd MK, Satten G, Cutler DJ, Pulver AE, Warren ST. 2010. Microdeletions of 3q29 confer high risk for schizophrenia. Am J Hum Genet 87(2):229-236.

Nylander L, Holmqvist M, Gustafson L, Gillberg C. 2013. Attention-deficit/hyperactivity disorder (ADHD) and autism spectrum disorder (ASD) in adult psychiatry. A 20-year register study. Nord J Psychiatry 67(5):344-350.

Ogata T, Ueno T, Hoshikawa S, Ito J, Okazaki R, Hayakawa K, Morioka K, Yamamoto S, Nakamura K, Tanaka S, Akai M. 2011. Hes1 functions downstream of growth factors to maintain oligodendrocyte lineage cells in the early progenitor stage. Neuroscience 176:132141.

Ornitz EM. 1969. Disorders of perception common to early infantile autism and schizophrenia. Comprehensive psychiatry 10(4):259-274.

Pinto D, Delaby E, Merico D, Barbosa M, Merikangas A, Klei L, Thiruvahindrapuram B, Xu X, Ziman R, Wang Z, Vorstman JA, Thompson A, Regan R, Pilorge M, Pellecchia G, Pagnamenta AT, Oliveira B, Marshall CR, Magalhaes TR, Lowe JK, Howe JL, Griswold AJ, Gilbert J, Duketis E, Dombroski BA, De Jonge MV, Cuccaro M, Crawford EL, Correia CT, Conroy J, Conceicao IC, Chiocchetti AG, Casey JP, Cai G, Cabrol C, Bolshakova N, Bacchelli E, Anney R, Gallinger S, Cotterchio M, Casey G, Zwaigenbaum L, Wittemeyer K, Wing K, Wallace S, van Engeland H, Tryfon A, Thomson S, Soorya L, Roge B, Roberts W, Poustka F, Mouga S, Minshew N, McInnes LA, McGrew SG, Lord C, Leboyer M, Le Couteur AS, Kolevzon A, Jimenez Gonzalez P, Jacob S, Holt R, Guter S, Green J, Green A, 
Gillberg C, Fernandez BA, Duque F, Delorme R, Dawson G, Chaste P, Cafe C, Brennan S, Bourgeron T, Bolton PF, Bolte S, Bernier R, Baird G, Bailey AJ, Anagnostou E, Almeida J, Wijsman EM, Vieland VJ, Vicente AM, Schellenberg GD, Pericak-Vance M, Paterson AD, Parr JR, Oliveira G, Nurnberger JI, Monaco AP, Maestrini E, Klauck SM, Hakonarson H, Haines JL, Geschwind DH, Freitag CM, Folstein SE, Ennis S, Coon H, Battaglia A, Szatmari P, Sutcliffe JS, Hallmayer J, Gill M, Cook EH, Buxbaum JD, Devlin B, Gallagher L, Betancur C, Scherer SW. 2014. Convergence of genes and cellular pathways dysregulated in autism spectrum disorders. Am J Hum Genet 94(5):677-694.

Pinto D, Pagnamenta AT, Klei L, Anney R, Merico D, Regan R, Conroy J, Magalhaes TR, Correia C, Abrahams BS, Almeida J, Bacchelli E, Bader GD, Bailey AJ, Baird G, Battaglia A, Berney T, Bolshakova N, Bolte S, Bolton PF, Bourgeron T, Brennan S, Brian J, Bryson SE, Carson AR, Casallo G, Casey J, Chung BH, Cochrane L, Corsello C, Crawford EL, Crossett A, Cytrynbaum C, Dawson G, de Jonge M, Delorme R, Drmic I, Duketis E, Duque F, Estes A, Farrar P, Fernandez BA, Folstein SE, Fombonne E, Freitag CM, Gilbert J, Gillberg C, Glessner JT, Goldberg J, Green A, Green J, Guter SJ, Hakonarson H, Heron EA, Hill M, Holt R, Howe JL, Hughes G, Hus V, Igliozzi R, Kim C, Klauck SM, Kolevzon A, Korvatska O, Kustanovich V, Lajonchere CM, Lamb JA, Laskawiec M, Leboyer M, Le Couteur A, Leventhal BL, Lionel AC, Liu XQ, Lord C, Lotspeich L, Lund SC, Maestrini E, Mahoney W, Mantoulan C, Marshall CR, McConachie H, McDougle CJ, McGrath J, McMahon WM, Merikangas A, Migita O, Minshew NJ, Mirza GK, Munson J, Nelson SF, Noakes C, Noor A, Nygren G, Oliveira G, Papanikolaou K, Parr JR, Parrini B, Paton T, Pickles A, Pilorge M, Piven J, Ponting CP, Posey DJ, Poustka A, Poustka F, Prasad A, Ragoussis J, Renshaw K, Rickaby J, Roberts W, Roeder K, Roge B, Rutter ML, Bierut LJ, Rice JP, Salt J, Sansom K, Sato D, Segurado R, Sequeira AF, Senman L, Shah N, Sheffield VC, Soorya L, Sousa I, Stein O, Sykes N, Stoppioni V, Strawbridge C, Tancredi R, Tansey K, Thiruvahindrapduram B, Thompson AP, Thomson S, Tryfon A, Tsiantis J, Van Engeland H, Vincent JB, Volkmar F, Wallace S, Wang K, Wang Z, Wassink TH, Webber C, Weksberg R, Wing K, Wittemeyer K, Wood S, Wu J, Yaspan BL, Zurawiecki D, Zwaigenbaum L, Buxbaum JD, Cantor RM, Cook EH, Coon H, Cuccaro ML, Devlin B, Ennis S, Gallagher L, Geschwind DH, Gill M, Haines JL, Hallmayer J, Miller J, Monaco AP, Nurnberger JI, Jr., Paterson AD, Pericak-Vance MA, Schellenberg GD, Szatmari P, Vicente AM, Vieland VJ, Wijsman EM, Scherer SW, Sutcliffe JS, Betancur C. 2010. Functional impact of global rare copy number variation in autism spectrum disorders. Nature 466(7304):368-372.

Purcell SM, Moran JL, Fromer M, Ruderfer D, Solovieff N, Roussos P, O'Dushlaine C, Chambert K, Bergen SE, Kahler A, Duncan L, Stahl E, Genovese G, Fernandez E, Collins MO, Komiyama NH, Choudhary JS, Magnusson PK, Banks E, Shakir K, Garimella K, Fennell T, DePristo M, Grant SG, Haggarty SJ, Gabriel S, Scolnick EM, Lander ES, Hultman CM, Sullivan PF, McCarroll SA, Sklar P. 2014. A polygenic burden of rare disruptive mutations in schizophrenia. Nature 506(7487):185-190.

Quintero-Rivera F, Sharifi-Hannauer P, Martinez-Agosto JA. 2010. Autistic and psychiatric findings associated with the 3q29 microdeletion syndrome: case report and review. Am J Med Genet A 152A(10):2459-2467.

Rapoport J, Chavez A, Greenstein D, Addington A, Gogtay N. 2009. Autism spectrum disorders and childhood-onset schizophrenia: clinical and biological contributions to a relation revisited. J Am Acad Child Adolesc Psychiatry 48(1):10-18.

Ripke S, O'Dushlaine C, Chambert K, Moran JL, Kahler AK, Akterin S, Bergen SE, Collins AL, Crowley JJ, Fromer M, Kim Y, Lee SH, Magnusson PK, Sanchez N, Stahl EA, Williams S, Wray NR, Xia K, Bettella F, Borglum AD, Bulik-Sullivan BK, Cormican P, Craddock N, de Leeuw C, Durmishi N, Gill M, Golimbet V, Hamshere ML, Holmans P, Hougaard DM, Kendler KS, Lin K, Morris DW, Mors O, Mortensen PB, Neale BM, O'Neill FA, Owen MJ, 
Milovancevic MP, Posthuma D, Powell J, Richards AL, Riley BP, Ruderfer D, Rujescu D, Sigurdsson E, Silagadze T, Smit AB, Stefansson H, Steinberg S, Suvisaari J, Tosato S, Verhage M, Walters JT, Multicenter Genetic Studies of Schizophrenia C, Levinson DF, Gejman PV, Kendler KS, Laurent C, Mowry BJ, O'Donovan MC, Owen MJ, Pulver AE, Riley BP, Schwab SG, Wildenauer DB, Dudbridge F, Holmans P, Shi J, Albus M, Alexander M, Campion D, Cohen D, Dikeos D, Duan J, Eichhammer P, Godard S, Hansen M, Lerer FB, Liang KY, Maier W, Mallet J, Nertney DA, Nestadt G, Norton N, O'Neill FA, Papadimitriou GN, Ribble R, Sanders AR, Silverman JM, Walsh D, Williams NM, Wormley B, Psychosis Endophenotypes International C, Arranz MJ, Bakker S, Bender S, Bramon E, Collier D, Crespo-Facorro B, Hall J, Iyegbe C, Jablensky A, Kahn RS, Kalaydjieva L, Lawrie S, Lewis CM, Lin K, Linszen DH, Mata I, McIntosh A, Murray RM, Ophoff RA, Powell J, Rujescu D, Van Os J, Walshe M, Weisbrod M, Wiersma D, Wellcome Trust Case Control C, Donnelly P, Barroso I, Blackwell JM, Bramon E, Brown MA, Casas JP, Corvin AP, Deloukas P, Duncanson A, Jankowski J, Markus HS, Mathew CG, Palmer CN, Plomin R, Rautanen A, Sawcer SJ, Trembath RC, Viswanathan AC, Wood NW, Spencer CC, Band G, Bellenguez C, Freeman C, Hellenthal G, Giannoulatou E, Pirinen M, Pearson RD, Strange A, Su Z, Vukcevic D, Donnelly P, Langford C, Hunt SE, Edkins S, Gwilliam R, Blackburn H, Bumpstead SJ, Dronov S, Gillman M, Gray E, Hammond N, Jayakumar A, McCann OT, Liddle J, Potter SC, Ravindrarajah R, Ricketts M, Tashakkori-Ghanbaria A, Waller MJ, Weston P, Widaa S, Whittaker P, Barroso I, Deloukas P, Mathew CG, Blackwell JM, Brown MA, Corvin AP, McCarthy MI, Spencer CC, Bramon E, Corvin AP, O'Donovan MC, Stefansson K, Scolnick E, Purcell S, McCarroll SA, Sklar P, Hultman CM, Sullivan PF. 2013. Genome-wide association analysis identifies 13 new risk loci for schizophrenia. Nat Genet 45(10):1150-1159.

Rizzolatti G, Craighero L. 2004. The mirror-neuron system. Annual review of neuroscience 27:169192.

Rizzolatti G, Fabbri-Destro M. 2010. Mirror neurons: from discovery to autism. Experimental brain research 200(3-4):223-237.

Rujescu D, Ingason A, Cichon S, Pietilainen OP, Barnes MR, Toulopoulou T, Picchioni M, Vassos E, Ettinger U, Bramon E, Murray R, Ruggeri M, Tosato S, Bonetto C, Steinberg S, Sigurdsson E, Sigmundsson T, Petursson H, Gylfason A, Olason PI, Hardarsson G, Jonsdottir GA, Gustafsson O, Fossdal R, Giegling I, Moller HJ, Hartmann AM, Hoffmann P, Crombie C, Fraser G, Walker N, Lonnqvist J, Suvisaari J, Tuulio-Henriksson A, Djurovic S, Melle I, Andreassen OA, Hansen T, Werge T, Kiemeney LA, Franke B, Veltman J, Buizer-Voskamp JE, Investigators G, Sabatti C, Ophoff RA, Rietschel M, Nothen MM, Stefansson K, Peltonen L, St Clair D, Stefansson H, Collier DA. 2009. Disruption of the neurexin 1 gene is associated with schizophrenia. Hum Mol Genet 18(5):988-996.

Sanders SJ, Ercan-Sencicek AG, Hus V, Luo R, Murtha MT, Moreno-De-Luca D, Chu SH, Moreau MP, Gupta AR, Thomson SA, Mason CE, Bilguvar K, Celestino-Soper PB, Choi M, Crawford EL, Davis L, Wright NR, Dhodapkar RM, DiCola M, DiLullo NM, Fernandez TV, Fielding-Singh V, Fishman DO, Frahm S, Garagaloyan R, Goh GS, Kammela S, Klei L, Lowe JK, Lund SC, McGrew AD, Meyer KA, Moffat WJ, Murdoch JD, O'Roak BJ, Ober GT, Pottenger RS, Raubeson MJ, Song Y, Wang Q, Yaspan BL, Yu TW, Yurkiewicz IR, Beaudet AL, Cantor RM, Curland M, Grice DE, Gunel M, Lifton RP, Mane SM, Martin DM, Shaw CA, Sheldon M, Tischfield JA, Walsh CA, Morrow EM, Ledbetter DH, Fombonne E, Lord C, Martin CL, Brooks AI, Sutcliffe JS, Cook EH, Jr., Geschwind D, Roeder K, Devlin B, State MW. 2011. Multiple recurrent de novo CNVs, including duplications of the 7q11.23 Williams syndrome region, are strongly associated with autism. Neuron 70(5):863-885.

Sebat J, Lakshmi B, Malhotra D, Troge J, Lese-Martin C, Walsh T, Yamrom B, Yoon S, Krasnitz A, Kendall J, Leotta A, Pai D, Zhang R, Lee YH, Hicks J, Spence SJ, Lee AT, Puura K, 
Lehtimaki T, Ledbetter D, Gregersen PK, Bregman J, Sutcliffe JS, Jobanputra V, Chung W, Warburton D, King MC, Skuse D, Geschwind DH, Gilliam TC, Ye K, Wigler M. 2007.

Strong association of de novo copy number mutations with autism. Science 316(5823):445449.

Sebat J, Lakshmi B, Troge J, Alexander J, Young J, Lundin P, Maner S, Massa H, Walker M, Chi M, Navin N, Lucito R, Healy J, Hicks J, Ye K, Reiner A, Gilliam TC, Trask B, Patterson N, Zetterberg A, Wigler M. 2004. Large-scale copy number polymorphism in the human genome. Science 305(5683):525-528.

Spek AA, Scholte EM, Van Berckelaer-Onnes IA. 2010. Theory of mind in adults with HFA and Asperger syndrome. J Autism Dev Disord 40(3):280-289.

Splawski I, Timothy KW, Sharpe LM, Decher N, Kumar P, Bloise R, Napolitano C, Schwartz PJ, Joseph RM, Condouris K, Tager-Flusberg H, Priori SG, Sanguinetti MC, Keating MT. 2004. $\mathrm{Ca}(\mathrm{V}) 1.2$ calcium channel dysfunction causes a multisystem disorder including arrhythmia and autism. Cell 119(1):19-31.

Stefansson H, Rujescu D, Cichon S, Pietilainen OP, Ingason A, Steinberg S, Fossdal R, Sigurdsson E, Sigmundsson T, Buizer-Voskamp JE, Hansen T, Jakobsen KD, Muglia P, Francks C, Matthews PM, Gylfason A, Halldorsson BV, Gudbjartsson D, Thorgeirsson TE, Sigurdsson A, Jonasdottir A, Jonasdottir A, Bjornsson A, Mattiasdottir S, Blondal T, Haraldsson M, Magnusdottir BB, Giegling I, Moller HJ, Hartmann A, Shianna KV, Ge D, Need AC, Crombie C, Fraser G, Walker N, Lonnqvist J, Suvisaari J, Tuulio-Henriksson A, Paunio T, Toulopoulou T, Bramon E, Di Forti M, Murray R, Ruggeri M, Vassos E, Tosato S, Walshe M, Li T, Vasilescu C, Muhleisen TW, Wang AG, Ullum H, Djurovic S, Melle I, Olesen J, Kiemeney LA, Franke B, Group, Sabatti C, Freimer NB, Gulcher JR, Thorsteinsdottir U, Kong A, Andreassen OA, Ophoff RA, Georgi A, Rietschel M, Werge T, Petursson H, Goldstein DB, Nothen MM, Peltonen L, Collier DA, St Clair D, Stefansson K. 2008. Large recurrent microdeletions associated with schizophrenia. Nature 455(7210):232-236.

Sudhof TC. 2008. Neuroligins and neurexins link synaptic function to cognitive disease. Nature 455(7215):903-911.

Sullivan PF, Daly MJ, O'Donovan M. 2012. Genetic architectures of psychiatric disorders: the emerging picture and its implications. Nature reviews Genetics 13(8):537-551.

Swillen A, McDonald-McGinn D. 2015. Developmental trajectories in 22q11.2 deletion. Am J Med Genet C Semin Med Genet 169(2):172-181.

Tateya T, Imayoshi I, Tateya I, Ito J, Kageyama R. 2011. Cooperative functions of Hes/Hey genes in auditory hair cell and supporting cell development. Dev Biol 352(2):329-340.

Vallipuram J, Grenville J, Crawford DA. 2010. The E646D-ATP13A4 mutation associated with autism reveals a defect in calcium regulation. Cell Mol Neurobiol 30(2):233-246.

Venkataraman A, Whitford TJ, Westin CF, Golland P, Kubicki M. 2012. Whole brain resting state functional connectivity abnormalities in schizophrenia. Schizophrenia research 139(1-3):712.

Votruba M, Thiselton D, Bhattacharya SS. 2003. Optic disc morphology of patients with OPA1 autosomal dominant optic atrophy. Br J Ophthalmol 87(1):48-53.

Walterfang M, Yung A, Wood AG, Reutens DC, Phillips L, Wood SJ, Chen J, Velakoulis D, McGorry PD, Pantelis C. 2008. Corpus callosum shape alterations in individuals prior to the onset of psychosis. Schizophrenia research 103(1-3):1-10.

Weingarten LS, Dave H, Li H, Crawford DA. 2012. Developmental expression of P5 ATPase mRNA in the mouse. Cell Mol Biol Lett 17(1):153-170.

Weischenfeldt J, Symmons O, Spitz F, Korbel JO. 2013. Phenotypic impact of genomic structural variation: insights from and for human disease. Nature reviews Genetics 14(2):125-138.

Willatt L, Cox J, Barber J, Cabanas ED, Collins A, Donnai D, FitzPatrick DR, Maher E, Martin H, Parnau J, Pindar L, Ramsay J, Shaw-Smith C, Sistermans EA, Tettenborn M, Trump D, de 
Vries BB, Walker K, Raymond FL. 2005. 3q29 microdeletion syndrome: clinical and molecular characterization of a new syndrome. Am J Hum Genet 77(1):154-160.

Xu B, Roos JL, Levy S, van Rensburg EJ, Gogos JA, Karayiorgou M. 2008. Strong association of de novo copy number mutations with sporadic schizophrenia. Nat Genet 40(7):880-885.

Zarrei M, MacDonald JR, Merico D, Scherer SW. 2015. A copy number variation map of the human genome. Nature reviews Genetics 16(3):172-183. 


\section{FIGURES LEGENDS}

Figure 1. Genealogical tree, qPCR results and the 3q29 deleted region identified. In panel A the pedigree of the family is depicted. Filled symbols indicate affected subjects; a short line above the symbol indicates available genomic DNA, while the arrow indicates the proband. Panel B shows gene quantification $(O P A 1)$ by real-time PCR on eight members of the family. In panel $\mathrm{C}$ the region deleted is reported with the nearby canonical 3q29 deletion defined between TRFC and DLG1 gene ( 195.7-197.3 Mb, hg19)(Cox and Butler 2015). Protein-coding genes are indicated as arrows, based on UCSC Genome Browser GRCh37/hg19 human assembly. 
A

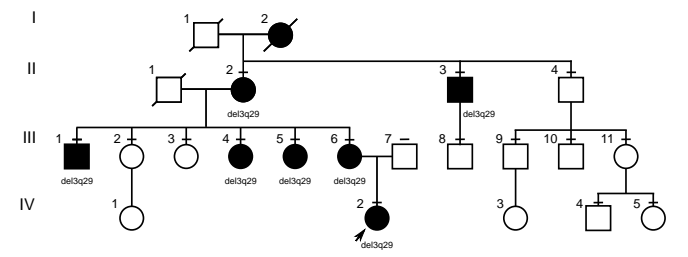

Cytogenetic Bands

$\begin{array}{r}3 \mathrm{q} 29 \\ \hline\end{array}$

RefSeq Genes(human assembly hg19)

$\underset{193 M}{1}{ }_{194 M}^{1 /}$

HRASLS
B

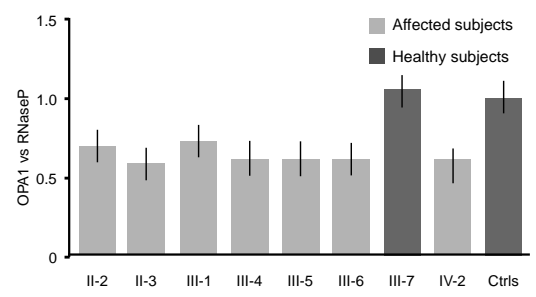


Figure 2

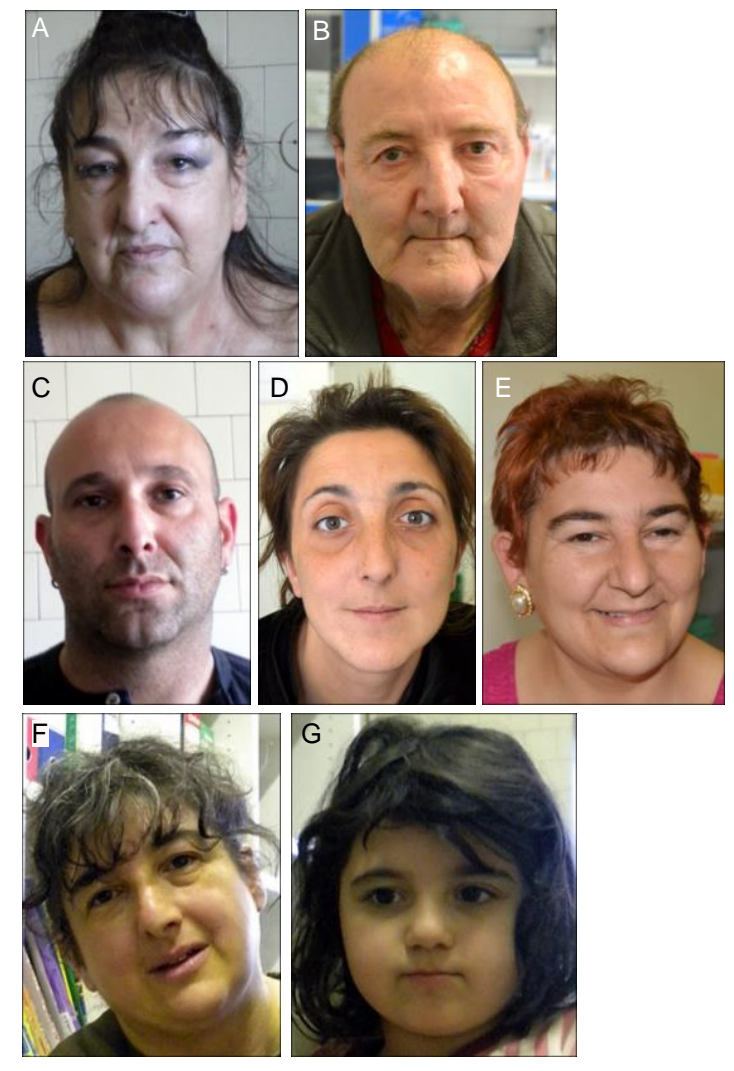


Table I. Phenotypic features of patients with 3q29 deletion.

\begin{tabular}{|c|c|c|c|c|c|c|c|}
\hline & II-2 & II-3 & III-1 & III-4 & III-5 & III-6 & IV-2 \\
\hline $\operatorname{Age}^{a}$ & $72 \mathrm{yrs}$. & 70 yrs. & $38 \mathrm{yrs}$. & $39 \mathrm{yrs}$. & $40 \mathrm{yrs}$. & 48 yrs. & 9 yrs. \\
\hline DD/ID & No & Yes & No & Yes & No & No & Yes \\
\hline $\begin{array}{l}\text { Psychiatric } \\
\text { disorder }\end{array}$ & $\begin{array}{c}\text { Dysthymia, } \\
\text { Avoidant Personality } \\
\text { Disorder }\end{array}$ & $\begin{array}{l}\text { Schizoaffective } \\
\text { disorder }\end{array}$ & $\begin{array}{c}\text { ASD, } \\
\text { Border-line } \\
\text { personality } \\
\text { disorder, } \\
\text { social anxiety } \\
\text { disorder }\end{array}$ & $\begin{array}{l}\text { Undifferentiated } \\
\text { schizophrenia }\end{array}$ & $\begin{array}{c}\text { Paranoid } \\
\text { schizophrenia }\end{array}$ & $\begin{array}{l}\text { Anxiety } \\
\text { disorder, } \\
\text { Major } \\
\text { depression }\end{array}$ & Autism \\
\hline Microcephaly & Yes & No & No & No & Yes & No & No \\
\hline Optic atrophy & Yes & n.a. & Yes & n.a. & n.a. & Yes & n.a. \\
\hline Hearing loss & Yes & Yes & No & n.a. & n.a. & No & No \\
\hline BMI & $\begin{array}{c}32 \\
\text { (Obese) }\end{array}$ & $\begin{array}{c}\text { n.a. } \\
\text { (Overweight) }\end{array}$ & $\begin{array}{c}29.2 \\
\text { (Overweight) }\end{array}$ & $\begin{array}{c}33.6 \\
\text { (Obese) }\end{array}$ & $\begin{array}{c}30.5 \\
\text { (Obese) }\end{array}$ & $\begin{array}{c}29.4 \\
\text { (Overweight) }\end{array}$ & $\begin{array}{c}27.8 \\
\text { (Overweight) }\end{array}$ \\
\hline Other & $\begin{array}{l}\text { Bilateral inguinal } \\
\text { hernia } \\
\text { Uterine fibroma } \\
\text { Hypertension }\end{array}$ & $\begin{array}{c}\text { Lumbar } \\
\text { scoliosis } \\
\text { Hypothyroidism } \\
\text { BPCO }\end{array}$ & & & & & Constipation \\
\hline
\end{tabular}

